\title{
横浜市内幼稚園児における食物アレルギーの実態調查 一幼稚園教諭と保護者へのアンケート調査一
}

\author{
伊藤 玲子11 石田華1) 只木弘 美1) \\ 横田俊平2) 相 原雄幸1) \\ 横浜市立大学附属市民総合医療センター 小児総合医療センター1) \\ 横浜市立大学大学院医学研究科発生成育小児医療学 ${ }^{2)}$
}

key words : 食物アレルギー, 幼稚園, 食物除去

\section{和文抄録}

入園前に耐性が獲得されない食物アレルギーの園児では, 幼稚園で食物アレルギーの症状がみられることも少 なくなく, 給食などに適切な対応が求められる. そこで, 幼稚園児における食物アレルギーの実態と問題点を明 らかにするため, 幼稚園教諭と保護者を対象にアンケート調査を行った。

173 園の幼稚園教諭と 1,148 人の保護者より有効回答を得た. 園児 29,106 人における食物アレルギーの有病率は $2.4 \%$ であった. 食物アレルギーの園児の $60 \%$ が幼稚園で食物除去が必要であった.

699 人の食物アレルギー児のうち，100人（14\%）に幼稚園で症状がみられた. 詳細が把握できた 61 名での原因 食品は, 鶏卵が 25 名, 牛乳 9 名, 魚介類 7 名, ピーナッツ 6 名であった。症状は皮膚症状が 38 名 $(62 \%)$, 喘鳴 4 名 $(7 \%)$, ショック症状 1 名（2\%）であった.

また，医師の診断書に基づいて食物除去を行っている幼稚園は $3 \%$ に過ぎなかった，さらに幼稚園教諭における 食物アレルギー症状の認識度は, 不十分であった。

幼稚園で安全に過ごすためには，スタッフへの教育が必要であると思われた。ささらに，食物除去や緊急時の対 応に関して, 主治医からの指示書の提出が望まれた.

はじめに

食物アレルギーは2歳以下の乳幼児の頻度が高い1,2). さらに, 保育施設における食物除去の割合も 0 歳を ピークに減少し，3歳以上では $2 \%$ 台と減少する ${ }^{3)}$. し かし, 集団生活を始める年齢までに食物除去が解除で きない園児では, 幼稚園での食事に適切な対応が求め られる。

富山県 ${ }^{4)}$ や愛知県 5 ) の幼稚園と保育園の調查では, 多 くの施設で除去食を提供しているとの報告されている. 今回我々は, 横浜市内の全幼稚園と一部の保護者を対 象にアンケート調査を行ったので報告する.

\section{対象と方法}

横浜市内の幼稚園 298 園の幼稚園教諭とそのうち市 内 8 区， 8 園に通園中の園児 1,610 人の保護者を対象に,
平成 14 年 12 月に郵送によるアンケート調査を実施し た. 両者に共通して，アレルギー性疾患の有病率や給 食などへの対応方法を調查した. また, 食物アレルギー の園児については, 幼稚園側が把握していた 387 名に 関して詳細に調查をした。幼稚園で実際に認められた 食物アレルギーの症状, 原因食物, 症状が誘発された 状況などについて調查した. さらに，幼稚園教諭にお ける，食物アレルギーの症状に関する認識度について 調査した.

今回の調査におけるアレルギー性疾患の判定は, 医 師の診断によるものだけでなく, 保護者の判断による 回答も含まれた。

\section{結 果}

\section{(1) 回答率}

173幼稚園（回答率 $58 \%$ ）より有効回答を得た。ま た 8 園の保護者へのアンケート調査では, 園児 1,148 人 
（男:女 $=560: 588 ）$ の保護者（回答率 $71 \%$ ）より有効 回答を得た。173園の総園児数は 35,779 人（男:女 $=18,272: 17,507)$, 対象年齢は3 歳から 6 歳であった. 幼稚園 1 園あたりの総園児数は, 平均約 200 人, 職員 数は平均 14 人であった.

\section{（2）アレルギー性疾患の有病率}

幼稚園 173 園のうち 169 園がアレルギ一性疾患につ いて情報収集を行っていた，その把握の機会としては， 多い順に(1)毎年度はじめの健康調查票, (2)健康診断,

(3)親からの申し出, (4)宿泊行事などの事前調查による ものであった。

アレルギー性疾患別の有病率が把握できた幼稚園 140 園（29,106人）の調査では，気管支喘息 $4.8 \% ， ア$ トピ一性皮膚炎 $4.1 \%$, 食物アレルギー $2.4 \%$, アレル ギー性鼻炎 $1.0 \%$ ，アレルギー性結膜炎 $0.2 \%$ であった

（表 1).一方，保護者の調査では，気管支喘息 $15.4 \%$ ， アトピー性皮膚炎 $14.4 \%$ ，食物アレルギー $3.8 \%$ ，アレ ルギー性鼻炎 $10.9 \%$ ，アレルギー性結膜炎 $4.4 \%$ であっ た. 保護者からの調査結果は, 幼稚園教諭の調査結果 と比較してすべてのアレルギー性疾患の頻度が高かっ
た（表 1). 直接保護者に質問した 8 園の幼稚園に対す る調査結果は，173園全体の結果と同様であった。ま た幼稚園の地域間格差はみられなかった。食物アレル ギーの有病率では，年齢ごとの有意差は認められな かった（図1).

（3）食物アレルギーの園児について

食物アレルギーの園児 699 名について個別に調査を 行った結果, 387 名について詳細を把握することがで きた.

これらの園児における他のアレルギー性疾患の有病 状況は,アトピー性皮膚炎が最も多く $33 \%$ (127/387名)， 気管支喘息 $22 \%$ (84/387名), アレルギー性鼻炎 $5 \%$ (18/387 名)，アレルギー性結膜炎 $2 \%$ （9/387名），薬 物アレルギー $1 \%$ （5/387名）であった。

食物アレルギーの原因食物では, 鶏卵が最も多く 256 名, 牛乳 106 名, 以下魚介類, そば, ピーナッツ, 小麦, 大豆の順であった（図2).このうち幼稚園で食 物除去を行っていた園児は，231/387名（60\%）であっ た。

食物除去の詳細が明らかであった 219 名では，一種

表 1. アレルギー疾患の有病率（\%)

\begin{tabular}{|c|c|c|c|c|c|c|}
\hline \multirow[t]{2}{*}{ 疾患 } & \multicolumn{3}{|c|}{ 幼稚国 } & \multicolumn{3}{|c|}{ 保菭者 } \\
\hline & 全体 & 男 & 女 & 全体 & 男 & 女 \\
\hline & $=29,106$ & 14,831 & 114,275 & $\mathrm{n}=1,148$ & 560 & 588 \\
\hline 気管支喘息 & 4.8 & 5.9 & 3.8 & 15.4 & 19.6 & 11.2 \\
\hline アトピー性皮膚炎 & 4.1 & 4.3 & 3.9 & 14.4 & 16.2 & 12.6 \\
\hline 食物アレルギー & 2.4 & 2.6 & 2.2 & 3.8 & 4.8 & 2.9 \\
\hline アレルギー性鼻炎 & 1.0 & 1.1 & 0.8 & 10.9 & 13.0 & 8.8 \\
\hline アレルギー性結膜炎 & $\leqslant 0.2$ & 0.2 & 0.2 & 4.4 & 5.2 & 3.6 \\
\hline
\end{tabular}

(\%)

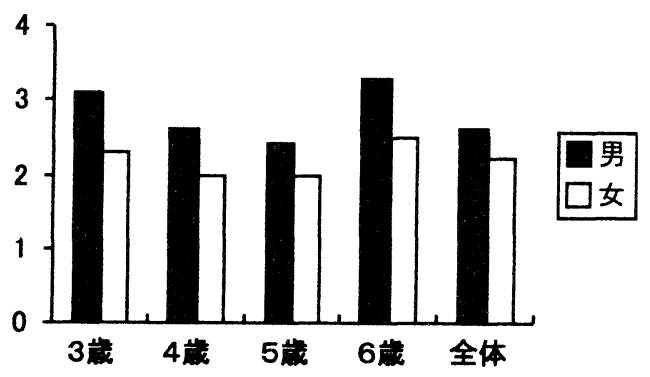

図 1. 食物アレルギーの有病率 $n=29,106$

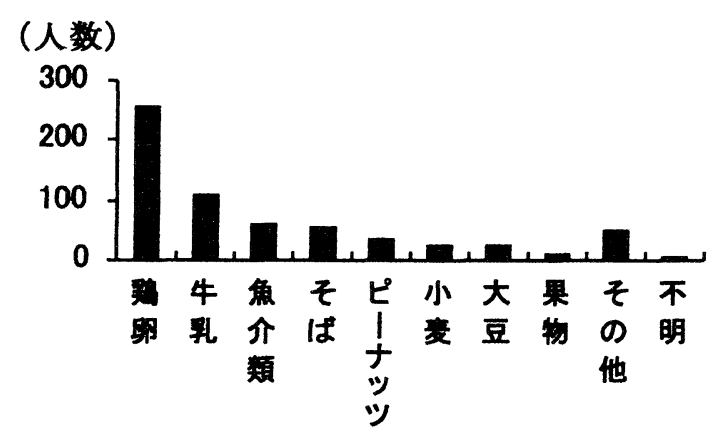

図 2. 食物アレルギ一の原因食物 $n=387$ 
類の食物を除去していたものは 174 名（79\%），2種類 が 24 名（11\%），3種類以上が 21 名（10\%）であった。 また, 幼稚園で除去している食物は, 鷄卵113名 (52\%), 牛乳 50 名 $(23 \%)$, そば 27 名 $(12 \%)$, 魚介類 22 名 (10\%)，ピーナッツ18名 (8\%)，小麦9名 $(4 \%)$, 大 豆9名 (4\%), その他31名（14\%）であった（図3）.

さらに, 保護者へのアンケート調査の結果では, 幼 稚園入園までに食物アレルギーの既往があった園児は, 全体の $12 \%$ （131/1148名, 男: 女 $=70: 61 ）$ であった. 現在も食物除去を継続している園児は，3\%（38名， 男 : 女 $=22: 16 ）$ であり，幼稚園入園前に食物除去が 解除できた園児は $71 \%$ （93/131名）であった。 入園前 に解除できた食物では, 頻度の高い順に, 大豆 $(7 / 7$ 名), 果物 (5/5名), 小麦 (8/9名), 魚介類 $(31 / 37$ 名), 牛乳 (25/31名), 卵 (48/67名), ピーナッツ (3/6名), そば（3/7名）であった。この結果より，そば，ピー ナッツの寛解率が低いことが示唆された（図4).

\section{（4）幼稚園の食事への対応方法}

幼稚園での食事に関しては, 給食などを提供してい る幼稚園は，136/173 園 $(79 \%)$, 回数は給食平均週 1.7 回, 間食週 0.3 回と少数であった. 調理場所は外部の 給食センターが 65 園と約半数を占めた.

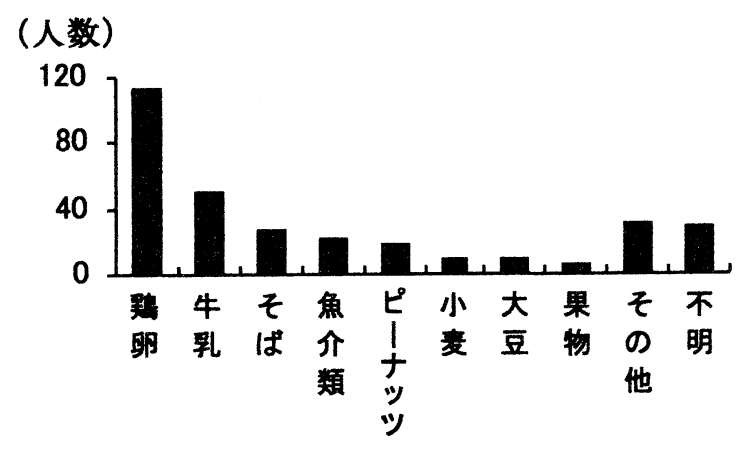

図3. 幼稚園にて除去している食物 $n=231$
食物アレルギーを有する園坚に対して特別な配慮を している幼稚園は，116/173 園（67\%）であった。 その うち，替わりにお弁当を持参してもらう対応をしてい るところが最も多く, 58 園であった. アレルゲンを除 去した食事や代替食を提供している園は71/173園のみ であった(表 2).この71園での食物除去への対応では, すべての該当食物に対応しているところが 36 園, 䳕卵, 牛乳のみがそれぞれ 19 園, 16 園であった. また食物除 去の程度としては, 二次製品も含めて対応していると ころは29園であった。

幼稚園で食物の除去を行っている理由では, 保護者 からの依頼が $94 \%$ と大部分であり, 医師からの診断書 によるものは少数であった.一方, 保護者へのアンケー トの結果では食物アレルギーの既往がある 131 名中 56 名より回答が得られた. 食物除去を始めた理由は医師 の診断によるとの回答が $73 \%$, 保護者自身の判断は $25 \%$ であった（表 3 ).

\section{（5）幼稚園での食事に関連した事故}

173 園中 $31 \%$ の幼稚園で 100 名の園児に, 食物アレル ギー症状を認めていた。これらに関して詳細な調査を 行った結果, 61 名の園児についての情報が得られた。

症状を 2 回以上繰り返していた園児は 10 名（男: 女

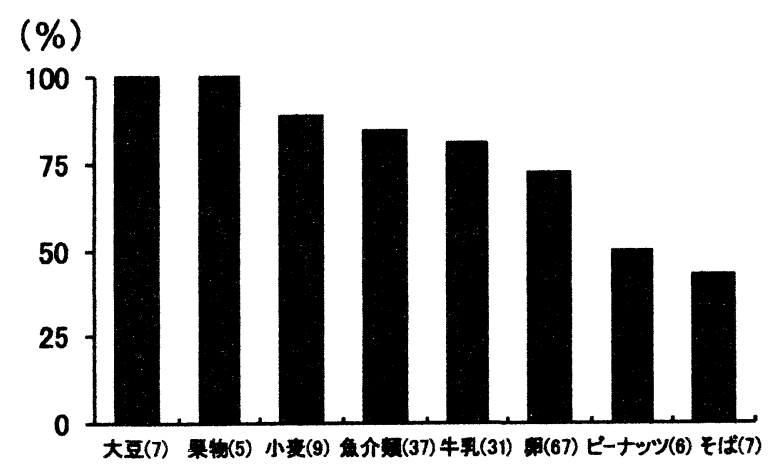

図 4. 食物ごとの寛解率 食物 $(n)$

表 2. 食物アレルギーの園児への食事の対応方法

$\begin{array}{lr}\text { お弁当を持参 } & 58 \text { 園 } \\ \text { アレルゲンを除去した同じメニューを提供 } & 39 \text { 園 } \\ \text { 別のメニューを提供 } & 32 \text { 園 } \\ \text { その他 } & 7 \text { 園 }\end{array}$


=7:3）認められた，症状が誘発された状況では，「間 違えてアレルゲンが混入していた」が最も多く 9/61名

(15\%)，「初回摂取」が8/61名（13\%)，「初めて症状 が見られた」が7/61名（12\%），「食物アレルギーの情 報がなかった」が 4/61名（7\%），その他 $9 / 61$ 名，不明 24/61名であった.

幼稚園でみられた症状としては皮膚症状が最も多く $38 / 61$ 名 (62\%)，目や鼻の症状 $5 / 61$ 名 (8\%)，喘鳴 $4 / 61$ 名 $(7 \%)$, 消化器症状 $1 / 61$ 名 (2\%), ショック症状 $1 / 61$ 名 $(2 \%)$, 不明 $12 / 61$ 名（20\%）であった.

原因食品では, 鶏卵が最も多く 25 名, 牛乳 9 名, 魚 介類 7 名, ピーナッツ 6 名, 小麦 5 名, そば 3 名, 大豆 2名であった（図5).

誘発症状は大部分の症例で食事開始後 30 分以内に みられ，2 時間以内に回復していた.

対処方法は, 親を呼んで帰宅させた, または様子を 見た園が大部分であった。しかし, 救急車を呼んだ園 が 3 園, 病院に搬送した幼稚園が 1 園みられた。その 中には，小麦アレルギーの園児が幼稚園で初めてホッ トケーキを食べて, ショック症状をおこしたという重 篤な例もみられた。

（6）幼稚園教諭における食物アレルギ一症状の認識度 幼稚園教諭に対して, 食物アレルギーの症状に関す
る認識度を調査した。 その結果, 䕒麻疹 $45 \%$, 湿疹 $63 \%$, 発赤 $47 \%$ と食物アレルギーの症状として最も頻度の 高い皮膚症状の認識さえ十分なものとは言えなかった (図6).

\section{考察}

横浜市内の幼稚園児における食物アレルギーの実態 調査を行った. その結果, 幼稚園で給食や間食を提供 する機会は少なく, 除去食を提供している幼稚園も少 数であった. 入園を制限している幼稚園もみられた. 多くの園では様々な方法で食物アレルギーの園児に配 慮し, 食物アレルギーの症状の発現を防ぐ努力がなさ れていた。しかしながら，31\%（54/173園）の幼稚園 で， $0.3 \%$ (100/35,579名）の園児に食物アレルギーの 症状が誘発されていた。

今回の調查における幼稚園児の食物アレルギーの頻 度は， $2.4 \%$ であった。これは川上らの報告 ${ }^{5}$ に近似し ており，また横浜市内の地域間格差も見られなかった。 さらに，食物除去を幼稚園入園前に解除できた園児は 71\% (93/131名)であり Egglestonの報告6) と同様であっ た.

一方, 給食などへの対応では, 富山県 4) や愛知県 5)

表 3. 幼稚園での食物除去の理由

\begin{tabular}{lccr}
\hline \multicolumn{2}{c}{ 幼稚國 } & & \multicolumn{2}{c}{ 保豳者 } \\
\hline 保護者からの依頼 & 218 名 $(94.4 \%)$ & 医師の診断 & 41 名 $(74 \%)$ \\
医師からの診断書 & 6 名 $(2.6 \%)$ & 保護者の判断 & 14 名 $(25 \%)$ \\
その他 & 7 名 $(3.0 \%)$ & その他 & 1 名 $(1 \%)$ \\
\hline
\end{tabular}

(\%)

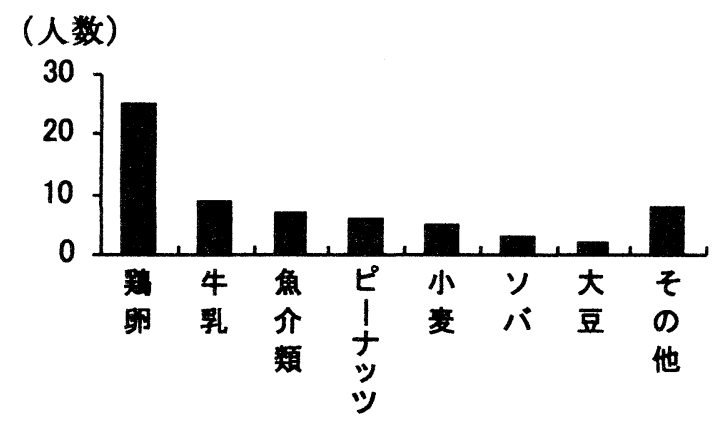

図 5. 幼稚園にて症状誘発の原因となった食物 $n=61$ （複数回答あり）

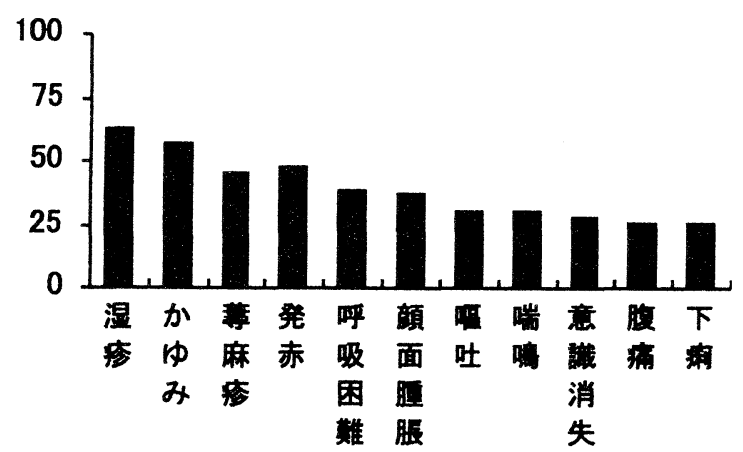

図6. 幼稚園教諭における食物アレルギ一症状の認識度 $n=173$ 
の保育施設調査の報告と比較して，幼稚園で除去食を 提供しているところは少数であり，お弁当持参による 対応が多かった。その理由としては，幼稚園では園览 の年龄層が高く，対象となる食物アレルギーの園児が 少ないこと, さらに保育時間も短く, 給食や間食など を提供する機会が少ないためと考えられた。

食物アレルギーでは食物除去を行う判断は必ずしも 容易でなく，不必要な食物除去が行われていたり，反 対に見過ごされている場合もみられる，保護者が食物 除去を始めたきっかけは，73\%が医師の診断であった が，幼稚園で実際に食物除去を行っているのは，ほと んどが保護者からの依頼で，医師の診断書に基づくの は3\%にすぎなかった. しかし, 直接医師からの指示 を受けないで, 幼稚園で食物アレルギーの園児に対応 するのは難しいと思われた。これに関して問題点はあ るものの, 地域によっては食物除去を行う際には, 医 師からの指示書の提出が必要となっている. 横浜市立 保育園においても平成 16 年 4 月より同様の対応が行わ れることになった. 今後幼稚園においても同様の対応 が望まれた。

また，幼稚園で把握されていたアレルギ一性疾患の 有病率と保護者からのものとにも差がみられた。これ は幼稚園での生活に支障があるほど重症でないため, 保護者からの申告が少なかったことなどが要因と思わ れた. さらに, 幼稚園教諭の食物アレルギーの症状に 関する認識度は十分とは言えない状況であった. 幼稚 園には養護教諭のように専門的な知識をもつたスタッ フがいないために, 食物除去の実施方法や症状誘発時 の対応に困っているとの意見も多く聞かれた.

欧米の子供をあずかる施設においては，食物アレル ギーの子供への対忘がなされている. 寸なわち, 緊急 時の対策マニュアルが作成され, エピネフリンを常備 するなど様々な取り組みがなされている7-12). またこ のような保育施設におけるガイドラインも作成されて いる13).

幼稚園での知識や情報不足による事故を防ぐために は，主治医からの指示書に基づく対策が必要であると 考えられた. すなわち, 指示書の内容としては, 食物 除去の実施方法や症状誘発時の対応方法などに関する 具体的な記載が不可欠であると思われた.さらに，緊 急時に速やかに対応できるように食物アレルギーを持 つ園児を把握しておく，それとともに，保育に関わる スタッフへの教育も必要であると思われた。
謝辞：今回のアンケート調査にご協力いただいた横浜 市幼稚園協会, 横浜市内幼稚園の幼稚園教諭, そして 保護者の方々に深謝いたします.

\section{参考文献}

1）柴田瑠美子. 即時型アレルギーの臨床. アレル ギー・免疫 2001; 8: 30-35.

2 ）今井孝成, 海老澤元宏. わが国の食物アレルギー の原因抗原. 小児科診療 2004; 27: 1056-1060.

3 ）伊藤節子, 平家俊男, 三河春樹. 保育園における 食品除去に関する実態調査. 平成 5 年度厚生省ア レルギー総合研究事業報告書 1995: 247-251.

4）足立陽子, 中林玄一, 淵沢竜也, 濱道美紀, 岡部 美恵，板沢寿子，足立雄一，村上巧啓，宮脇利男。 保育施設における食物アレルギー児に対する食物 除去の実態一富山県における調查結果一。日本小 児アレルギー学会誌 2004; 18: 100-107.

5）川上伸子, 眯 裕篤, 竹内三奈, 鶴澤正仁, 藤本 孟男, 田中 潤. 食物アレルギー児の給食におけ る問題点 第 2 報 保育園・幼稚園へのアンケー 卜調查. 日本小巟アレルギ一学会誌 $2001 ; 15: 527-$ 533.

6 ) Eggleston PA.Prospective studies in the natural history of food allergy.Ann Allergy 1987; 59: 179182.

7) Moneret-Vautrin DA, Kanny G, Morisset M, Flabbee J, Guenard L,Beaudouin E, Parisot L. Food anaphylaxis in schools:evaluation of the management plan and the efficiency of the emergency kit. Allergy 2001; 56: 1071-1076.

8 ) Truglio-Londrigan M, Macali MK, Bernstein M, Kaider G, Petersen S, Tumino MC. A plan for the delegation of epinephrine administration in nonpublic schools to unlicenced assistive personnel. Public Health Nurs 2002; 19: 412-422.

9 ) Rhim GS, McMorris MS. School readiness for children with food allergies. Ann Allergy Asthma Immunol 2001; 86: 172-176.

10) Moneret-Vautrin DA, Kanny G. Anaphylaxis in schools and other child-care settings-the situation in France. Allerg Immunol 1999; 31: 141-144.

11) Gaudreau JM. The challenge of making the school environment safe for children with food allergies. J 
Sch Nurs 2000; 16: 5-10.

12) Nowak-Wegrzyn A, Conover-Waker MK, Wood RA. Food-allergic reactions in schools and preschools. Arch Pediatr Adolesc Med 2001; 155: 790-795.
13) AAAAI Board of Directors. Anaphylaxis in schools and other childcare settings. J Allergy Clin Immunol 1998; 102: 173-176.

\title{
FOOD ALLERGIC REACTIONS IN KINDERGARTENS: SURVEY OF CHILDREN WITH FOOD ALLERGIES AT KINDERGARTENS IN YOKOHAMA CITY
}

\author{
Reiko Ito $^{1)}$, Hana Ishida $^{1)}$, Hiromi Tadaki $^{1}{ }^{1}$, Shumpei $_{\text {Yokota }}{ }^{2}$, ,ukoh Aihara $^{1)}$ \\ Department of Pediatrics Yokohama City University Medical Center ${ }^{1}$, \\ Department of Pediatrics Yokohama City University School of Medicine ${ }^{2)}$
}

\begin{abstract}
Food allergic children require special support as food allergic reactions may occur in kindergartens. However, information regarding kindergarten readiness for children with food allergies is not well known. To identify prevention and treatment policies for food allergic children at kindergartens, we mailed a questionnaire to kindergarten teachers and parents to assess the prevalence of food allergies among children, their management plan for lunches, the types of reaction that occur, and staff awareness of food allergies.

One hundred and seventy-three kindergartens and 1,148 parents from eight kindergartens completed the questionnaire. Of 29,106 children, $2.4 \%$ had a food allergy. Sixty percent of food allergic children required food elimination at kindergarten.

Fourteen percent (100/699) of food allergic children experienced food allergic reactions at kindergartens. Reactions were reported to egg (25/61), milk (9/61), fish (including shellfish) (7/61), and peanuts (6/61). The symptoms were mostly skin symptoms (38 children; $62 \%$ ), but, wheezing was seen in four (7\%), and hypotension was seen in one child.

Finally, only $3 \%$ of kindergartens had received instructions from physicians regarding management at kindergarten. Furthermore, kindergarten teachers were found to have a poor understanding of food allergies.

To keep food allergic children safe in kindergartens, there appears to be a need to educate staff about food allergies. Moreover, detailed instructions from the physicians of children in case of emergencies and for prevention are required.
\end{abstract}

